\title{
A Comparative Study On Employee Productivity Of Amreli Jilla Madhyasth Sahkari Bank And The Baroda Central Cooperative Bank.
}

\author{
Dr. Nitin J. Dhamsaniya And Dr. Achyut C. Patel \\ Smt. M.T. Dhamsania College of Commerce, Kalawad Road, Rajkot
}

\begin{abstract}
The efficiency or the development of a bank can be plumbed by different measures like deposits, advances, working assets, incomes, expenditures, profits, no of assets, number of accounts and branches etc. The role of employees is also of great signification as each \& every expression of a bank is directly affiliated to the attitude, motivation \& work civilisation of the employees. so the parameters which are used to count the efficiency, should also incorporate the performance of their employees. In the current study the employee performance reasoning of selected co.opt bank has been performed on the basis of 2 ratios. a). working funds / employee b). operating profit / employee ratio. In this research article researcher study the employee work productivity of BCC \& AJMB bank.
\end{abstract}

Keywords: Employee Productivity

\section{INTRODUCTION}

Productivity has now transformed a daily countersign. The 2 fundamental approaches to market relevant prosperity are

(1) Right allocation of accessible resources among their alternative use

(2) The somebody attemptable utilization of specified allotted resources.

It is indeed in production of many and improve output from donated intensity of resources and conferred output from lesser or cheaper resources that the covert of tangible advancement lies and it this info that is popularly termed as "fecundity"

We can say that "Productivity is the ratio between the output given commodity calculated by it's intensity and one more of the sign factor also calculated by their volumes".

"Productivity is the efficiency which goods and services are produced the ratio of the outturn of goods and services to the input of resources. The wordbook thought of productivity is "the quality or fact being productive", while "productivity means having character of production or transportation onward" According to world encyclopaedia of social science (1968) "productivity refer to a class of empirical output-input ratio that is widely used in economic history, economic analysis and economic policy".

\section{OVERVIEW OF SELECTED BANK}

1. $\mathrm{AJMB}$

2. $\mathrm{BCCB}$

\section{A. Amreli jilla madhyasth sahkari bank Ltd.}

This bank was founded in 1910 in medieval vadodara state. It was names as "The Amreli Khetivadi Pedhi Ltd". It was registered under the cooperative act on 23/08/1950 (registration No. 19170/2). Later on when Gujarat became a separate state in 1660 , this bank started working as a district cooperative bank under the cooperative acts. Since 1950 the bank obtaining Audit Class ' $\mathrm{A}$ '. This is an excellent achievement. The bank has undergone many changes and revolution in its long journey with the help of admirable service by its Ex-president Mr. Dwarkadas Patel and respected presents time president Mr. Dilipbhai Sanghani.

The bank has bagged the best performance award in 1999-2000. It has won many prizes given by Gujarat state co-operative bank ltd. In 2006-07 the bank achieved the 'Best Banker' award by D.R.D.A. under the S.G.S.Y. scheme. There are 68 branches of the bank most of them are working in rural areas. The banks work under the Gujarat co-operative societies act, 1961 and R.B.I. Guidelines. The economic reforms and the process of globalization, privatisation and liberalization brought in competitive attitudes among the banks. The change made it inevitable that the bank must be reliable working fast and the analysis is to be made time to time. This resulted into the computerization of all the 68 branches.

Table 1: General Performance of AJMS bank, Amreli

\begin{tabular}{|c|c|c|c|c|c|}
\hline Sr. No. & Particular & $\mathbf{2 0 0 3 - 0 4}$ & $\mathbf{2 0 0 9 - 1 0}$ & $\mathbf{2 0 1 2 - 1 3}$ & $\begin{array}{c}\text { Percentage } \\
\text { increase over 2002 } \\
\text { to 13 }\end{array}$ \\
\hline 1 & No. Of Branches & 39 & 52 & 68 & 74.36 \\
\hline 2 & Share Capital & 1008.92 & 1037.66 & 1326.19 & 31.45 \\
\hline 3 & Reserve \& Surplus & 1057.77 & 1908.23 & 2323.80 & 119.67 \\
\hline 4 & Deposit & 11934.67 & 24826.94 & 37960.49 & 218.07 \\
\hline 5 & Borrowing & 2697.04 & 13216.57 & 48248.40 & 1688.94 \\
\hline 6 & Advances & 10324.73 & 18587.12 & 40745.05 & 294.64 \\
\hline 7 & Profit & 240 & 161.66 & 380.05 & 58.35 \\
\hline
\end{tabular}


International Journal of Trend in Scientific Research and Development, Volume 1(1), ISSN: 2456-6470 www.ijtsrd.com

Table 2: General Performance of BCC bank, Vadodara

\begin{tabular}{|c|c|c|c|c|c|}
\hline Sr. No. & Particular & $\mathbf{2 0 0 3 - 0 4}$ & $\mathbf{2 0 0 9 - 1 0}$ & $\mathbf{2 0 1 2 - 1 3}$ & $\begin{array}{c}\text { Percentage increase } \\
\text { over 2002 to 13 }\end{array}$ \\
\hline 1 & No. Of Branches & 36 & 36 & 36 & 0 \\
\hline 2 & Share Capital & 6112.44 & 6114.84 & 6224.10 & 1.83 \\
\hline 3 & Reserve \& Surplus & 2817.97 & 6271.15 & 8770.45 & 211.23 \\
\hline 4 & Deposit & 20607.93 & 35860.95 & 45571.59 & 121.14 \\
\hline 5 & Borrowing & 12282.87 & 1203.48 & 1180 & -90.37 \\
\hline 6 & Advances & 20345.56 & 20693.60 & 20381.54 & 0.17 \\
\hline 7 & Profit & - & 1525.27 & 615.08 & - \\
\hline 8 & Loss & 1061.51 & - & - & - \\
\hline
\end{tabular}

\section{B. The Baroda Central Cooperative Bank Ltd.}

The baroda central cooperative bank was founded on 26/04/1913 (Registration No. 173/69) as the " The Vadodara Madhyasth Shakari Bank'. The bank has performed outstandingly in Quality services in the region of Vadodara District. The name of the bank was changed to The Baroda Central Cooperative bank in 1950 with new registration number 19192 (Dt. 29/01/1950) under Gujarat state cooperative Society Act. The population of 36.40 lack people is leving in 12 talukas. The geographical area is 779798 sq. $\mathrm{Km}$. which included new sown area of 540436 hectare. The Vadodra district falls under the Gol's declared agriculture export zone. The major crops grown in the district are cotton, sugarcane, tur, tobacco, arhar and paddy. Banana, Mango and Chickoo are the main horticultural crops. Vegetables are grown extensively in Padra and Vadodara blocks. Tomatoes are cultivated on a large scale in the tribal belt of Chota udepur. Some of the big industries located in the district are Gujarat State Fertilizer Corporation, Gujarat Refinery, Gujarat Communication and Electronics, IPCL. Reliance Petrifies, ONGC, etc. In the bank all the branches and the head office are computerized in order to provide fast and effective services. The bank provides locker facility, life insurance and general insurance to the members.

\section{RESEARCH METHEDOLOGY}

\section{A. Title of the Study}

"A Comparative study on productivity of Amreli jilla Madhyasth sahkari bank and The Baroda central cooperative bank."

\section{B. Review of Literature}

Carlos et al. (2005) studied productivity changes in European co- operative banks and concluded that an effective use of technology between 1996 and 2003 had increased productivity for majority of the European co-operative banks under study. An appropriate policy recommendation by the researchers was for larger or centralized co-operative banks to develop and franchise technology to smaller cooperatives.

Satyanarayane (1996) studied productivity beyond per employee business, and suggested a model to measure overall efficiency of the banks. He emphasised that the size of the bank should be squared off while measuring efficiency of bank. According to him, Productivity of bank $=($ Average index market share of all the output factors/Average index market share of all the input factors) X 100 where, output factors were deposits, non-deposit working funds, loans \& advances, investments, interest spread, non-interest income and the net profit. The input factors were network of branches, number of staff, wage bill, non-wage operating expenses, etc. In order to facilitate comparison of one bank with the other, irrespective of size, the market share of each factor in percentage terms has to be taken into account instead of absolute levels.

In 1978 study titled called by Bhatia, "Banking Structure and Performance - A Case Study of the Indian Banking System" attempted to examine the economic execution in Indian banking sector as reflected by its turnout, cost $\&$ profit during the phase 1950-1968. During his study he concludes that profit of banking during the said phase had an ascending trend. His study learning liberation of interest rate to increase the profit of any financial institutions and to assure a aggressive banking in which good result with better services.

In 2006 paper entitles by Mohan "Reforms Productivity and Efficiency in Banking: The Indian Experience" analysed that the clinical of reforms in generalised is to intensify the development force of the economy, delimited in there of per capita income. Not surprisingly, hence execution of banking sector has repercussions crossways the size and breadth of the economy. Financial business intercession is essential to the encouragement of both comprehensive \& intensive development. So development of the business system is constitutional to the procreation of higher fruitfulness and economic development.

In 1999 by V.K. Bhatasana studied the assessment of financial execution of SBI(1980-1995) especially productivity \& profit of SBI during the stud period, Mr. Bhatasana observed quality of capital funds, deposits growth, enlargement of branches in rural area and less borrowing from RBI. During this period SBI improved the productivity and profit of SBI among public sector banks.

\section{Objective}

1. To know financial performance of selected district cooperative AJM and BCC bank of Gujarat State.

2. To examine the Employee Profitability of selected District Co-operative AJM and BCC bank of Gujarat State.

3. To enlist the Finding and Conclusion. 
4. To make suggestions for batter improving performance.

\section{Hypothesis}

\section{$>$ Null hypothesis (Ho):}

There would be no significant difference in Percentage of Ratio of AJM and BCC Bank.

$>$ Alternative hypothesis (H1):

There would be significant difference in Percentage of Ratio of AJM and BCC Bank.

\section{E. Universe of the Study}

Here all District Central Co-operative Banks which are working in Gujarat are as a universe of the study.

\section{F. Sample Design}

There were 18 District Central cooperative banks in Gujarat with included 1 Taluka cooperative banking union. The researcher has randomly selected Two District central cooperative banks.

\section{G. Data Collection:}

The data collection is very important task for the researcher for the research study. This research study is mainly based on secondary data. The secondary data shall be collected from the records, documents, related subject matter and related web side. Personal visits and unstructured interviews with the officials of the District Co-operative Banks are also the main source of the data. Besides, the researcher shall collect and analyze published data as per the requirement.

\subsection{Use of Tools and Techniques:}

Here, mainly applied test or techniques are as under.

1. F-Test ANOVA (Analysis of Variances)

2. Ratio Analysis

\section{DATA ANALYSIS}

\section{A. Deposit per Employee}

\begin{tabular}{|c|c|c|}
\hline \multirow{2}{*}{ Year } & \multicolumn{2}{|c|}{ Selected Cooperative banks } \\
\cline { 2 - 3 } & AJMB & BCCB \\
\hline $2003-04$ & 0.5281 & 1.1200 \\
\hline $2004-05$ & 0.4921 & 1.1000 \\
\hline $2005-06$ & 0.3750 & 1.2175 \\
\hline $2006-07$ & 0.4428 & 1.6017 \\
\hline $2007-08$ & 0.5051 & 2.1876 \\
\hline $2008-09$ & 0.6238 & 2.7367 \\
\hline $2009-10$ & 0.8445 & 3.4482 \\
\hline $2010-11$ & 1.1358 & 4.0554 \\
\hline $2011-12$ & 1.1399 & 4.0047 \\
\hline $2012-13$ & 0.9038 & 4.6981 \\
\hline
\end{tabular}

F-Test (ANOVA) of Deposit / Employee

\begin{tabular}{|c|r|r|r|r|r|}
\hline Variation & \multicolumn{1}{|c|}{ SS } & \multicolumn{1}{c|}{ Df } & MS & \multicolumn{1}{c|}{ F } & F crit \\
\hline Between Years & 11.8854 & 9 & 1.3206 & 2.123986 & 3.178893 \\
\hline Between Banks & 18.3917 & 1 & 18.3917 & 29.58027 & 5.117355 \\
\hline Error & 5.595801 & 9 & 0.621756 & & \\
\hline Total & 35.8729 & 19 & & & \\
\hline
\end{tabular}

Between Banks: F value $>$ Table value

Concluded that there is significance difference between Banks Rate of Deposit per Employee Ratio of selected AJM and BCC District Co-operative Banks in Gujarat.

\section{B. Advances per Employee}


International Journal of Trend in Scientific Research and Development, Volume 1(1), ISSN: 2456-6470 www.ijtsrd.com

\begin{tabular}{|c|c|c|}
\hline \multirow{2}{*}{ Year } & \multicolumn{2}{|c|}{ Selected Cooperative banks } \\
\cline { 2 - 3 } & AJMB & BCCB \\
\hline $2003-04$ & 0.4568 & 1.1057 \\
\hline $2004-05$ & 0.5608 & 1.4079 \\
\hline $2005-06$ & 0.4997 & 1.4070 \\
\hline $2006-07$ & 0.4684 & 1.6551 \\
\hline $2007-08$ & 0.5102 & 1.9633 \\
\hline $2008-09$ & 0.6542 & 1.9347 \\
\hline $2009-10$ & 0.6322 & 1.9898 \\
\hline $2010-11$ & 0.7514 & 1.4612 \\
\hline $2011-12$ & 1.2437 & 2.1109 \\
\hline $2012-13$ & 0.9701 & 2.1012 \\
\hline
\end{tabular}

F-Test (ANOVA) of Advances / Employee

\begin{tabular}{|c|r|r|r|r|r|}
\hline Variation & \multicolumn{1}{|c|}{ SS } & \multicolumn{1}{c|}{ Df } & \multicolumn{1}{c|}{ MS } & \multicolumn{1}{c|}{ F } & F crit \\
\hline Between Years & 1.346639 & 9 & 0.149627 & 3.8157 & 3.178893 \\
\hline Between Banks & 5.396878 & 1 & 5.396878 & 137.6284 & 5.117355 \\
\hline Error & 0.352921 & 9 & 0.039213 & & \\
\hline Total & 7.096437 & 19 & & & \\
\hline
\end{tabular}

Between Banks: F value $>$ Table value

\section{Total Business per Employee}

\begin{tabular}{|c|c|c|}
\hline \multirow{2}{*}{ Year } & \multicolumn{2}{|c|}{ Selected Cooperative banks } \\
\cline { 2 - 3 } & AJMB & BCCB \\
\hline $2003-04$ & 0.9849 & 2.2257 \\
\hline $2004-05$ & 1.0529 & 2.5079 \\
\hline $2005-06$ & 0.8747 & 2.6245 \\
\hline $2006-07$ & 0.9112 & 3.2568 \\
\hline $2007-08$ & 1.0153 & 4.1509 \\
\hline $2008-09$ & 1.2779 & 4.6714 \\
\hline $2009-10$ & 1.4767 & 5.4379 \\
\hline $2010-11$ & 1.8871 & 5.5166 \\
\hline $2011-12$ & 2.3836 & 6.1156 \\
\hline $2012-13$ & 1.8739 & 6.7993 \\
\hline
\end{tabular}

F-Test (ANOVA) of Total Business / Employee

\begin{tabular}{|c|r|r|r|r|r|}
\hline Variation & \multicolumn{1}{|c|}{ SS } & \multicolumn{1}{c|}{ Df } & MS & F & F crit \\
\hline Between Years & 19.68201 & 9 & 2.18689 & 2.984198 & 3.178893 \\
\hline Between Banks & 43.71451 & 1 & 43.71451 & 59.65221 & 5.117355 \\
\hline Error & 6.595408 & 9 & 0.732823 & & \\
\hline Total & 69.99193 & 19 & & & \\
\hline
\end{tabular}

Between Banks: F value $>$ Table value 
International Journal of Trend in Scientific Research and Development, Volume 1(1), ISSN: 2456-6470 www.ijtsrd.com

It is concluded that there is significance difference between Banks Rate of Total Business per Employee of selected AJM and BCC District Co-operative Banks in Gujarat.

\section{Net Profit per Employee}

\begin{tabular}{|c|c|c|}
\hline \multirow{2}{*}{ Year } & \multicolumn{2}{|c|}{ Selected Cooperative banks } \\
\cline { 2 - 3 } & AJMB & BCCB \\
\hline $2003-04$ & 0.0106 & -0.0577 \\
\hline $2004-05$ & 0.0077 & 0.1047 \\
\hline $2005-06$ & 0.0080 & -0.0244 \\
\hline $2006-07$ & 0.0025 & -0.1469 \\
\hline $2007-08$ & 0.0060 & -0.1055 \\
\hline $2008-09$ & 0.0034 & -0.0252 \\
\hline $2009-10$ & 0.0055 & 0.1467 \\
\hline $2010-11$ & 0.0061 & 0.2528 \\
\hline $2011-12$ & 0.0104 & 0.0728 \\
\hline $2012-13$ & 0.0090 & 0.0634 \\
\hline
\end{tabular}

F-Test (ANOVA) of Net Profit / Employee

\begin{tabular}{|c|r|r|r|r|r|}
\hline Variation & \multicolumn{1}{|c|}{ SS } & \multicolumn{1}{c|}{ Df } & \multicolumn{1}{|c|}{ MS } & \multicolumn{1}{c|}{ F } & F crit \\
\hline Between Years & 0.068232 & 9 & 0.007581 & 1.019351 & 3.178893 \\
\hline Between Banks & 0.002237 & 1 & 0.002237 & 0.300727 & 5.117355 \\
\hline Error & 0.066936 & 9 & 0.007437 & & \\
\hline Total & 0.137404 & 19 & & & \\
\hline
\end{tabular}

Between Banks: F value $<$ Table value

Concluded that there is no significance difference between Banks Rate of Net Profit per Employee Ratio of selected AJM and BCC District Co-operative Banks in Gujarat.

\section{E. Working Fund per Employee}

\begin{tabular}{|c|c|c|}
\hline \multirow{2}{*}{ Year } & \multicolumn{2}{|c|}{ Selected Cooperative banks } \\
\cline { 2 - 3 } & AJMB & BCCB \\
\hline $2003-04$ & 0.7714 & 2.0893 \\
\hline $2004-05$ & 0.8101 & 1.9830 \\
\hline $2005-06$ & 0.6955 & 2.0494 \\
\hline $2006-07$ & 0.7559 & 2.6015 \\
\hline $2007-08$ & 0.8872 & 3.0851 \\
\hline $2008-09$ & 1.1120 & 3.3495 \\
\hline $2009-10$ & 1.4762 & 4.0611 \\
\hline $2010-11$ & 1.9247 & 4.8061 \\
\hline $2011-12$ & 2.5129 & 5.3308 \\
\hline $2012-13$ & 2.2194 & 6.0354 \\
\hline
\end{tabular}


International Journal of Trend in Scientific Research and Development, Volume 1(1), ISSN: 2456-6470 www.ijtsrd.com

F-Test (ANOVA) of Working Fund / Employee

\begin{tabular}{|c|r|r|r|r|r|}
\hline Variation & \multicolumn{1}{|c|}{ SS } & \multicolumn{1}{c|}{ Df } & \multicolumn{1}{c|}{ MS } & \multicolumn{1}{c|}{ F } & F crit \\
\hline Between Years & 20.16656 & 9 & 2.240729 & 6.426014 & 3.178893 \\
\hline Between Banks & 24.69953 & 1 & 24.69953 & 70.83389 & 5.117355 \\
\hline Error & 3.138269 & 9 & 0.348697 & & \\
\hline Total & 48.00436 & 19 & & & \\
\hline
\end{tabular}

\section{Between Banks: F value > Table value}

Concluded that there is significance diff between Banks Rate of Working Fund per Employee Ratio of selected AJM and BCC District Co-operative Banks in Gujarat.

\section{CONCLUSION}

Analysis of EMPLOYEE PRODUCTIVITY above five Ratios under the study by sample of AJM and BCC District Cooperative Bank and, the results obtained from ' $\mathrm{F}$ ' test (ANOVA) at 5 percent level of significance it is concluded that there is significance difference between Banks in most of Ratio of EMPLOYEE PRODUCTIVITY Ratios of selected AJM and BCC District Co-operative Banks in Gujarat.

\section{Reference}

1. Annual report of Amreli jilla madhyasth sahkari bank from 2003-04 to 2012-13

2. Annual report of baroda central cooperative bank from 2003-04 to 2012-13

3. "Industrial Productivity and Economic Growth", chaitanya Publishing House, Allahabad, P.16 - Lal B.B.

4. "Productivity" Productivity News Vol. XXIV No.02 April (1986) P.22 - Dr. Jain D.C.

5. Dubin Robert, "Human Relation in Administration" Delhi Prentice Hall Of India, (1979) P.510

6. "Measuring Ado Productivity", Vol. XXVi, No.4 Jan. March., (1986) P.335 - Talukdar R.K. and S.N. Laheriam 